\title{
Model Kepuasan Pelanggan di PT Mediacomm Citra Perdana
}

\author{
Model of Customer Satisfaction in PT Mediacomm Citra Perdana
}

\author{
Roy Dharma Muliawan ${ }^{1^{*}}$, Ma'mun Sarma ${ }^{2 \sharp}$, dan Soewarno T. Soekarto ${ }^{3 \sharp}$ \\ ${ }^{1}$ Kementerian Kelautan dan Perikanan \\ Gd. Mina Mitra Bahari Jl. Medan Merdeka Barat, Jakarta \\ ${ }^{2}$ Departemen Manajemen, Fakultas Ekonomi dan Manajemen IPB \\ ${ }^{3}$ Departemen Ilmu dan Teknologi Pangan, Fateta IPB \\ *Jl. Kamper, Kampus IPB Darmaga, Bogor 16680
}

\begin{abstract}
ABSTRAK
Kepuasan pelanggan akan tercapai apabila kinerja dan mutu pelayanan yang dialami sesuai dengan yang diharapkan. PT Mediacomm Citra Perdana adalah sebuah perusahaan yang bergerak di bidang jasa komunikasi dalam bentuk iklan. Dalam pelaksanaannya, melakukan pembuatan iklan dan pencarian klien, PT Mediacomm Citra Perdana menghadapi persaingan. Budaya kerja yang dijadikan tradisi di dalam pelayanan, adalah cepat, akurat dan profesional. Tujuan penelitian ini (1) Mengidentifikasi persepsi pelanggan; (2) Menganalisis pengaruh mutu produk; dan (3) Mengidentifikasi faktor mutu produk, Pelayanan jasa dan Tenaga pemasaran yang perlu diperbaiki dan dipertahankan oleh PT Mediacomm Citra Perdana. Pengumpulan data dilakukan dengan kuesioner skala likert dan teknik penarikan purposive sampling serta menggunakan metode analisis deskriptif untuk menggambarkan karakteristik konsumen, proses pelayanan dan mutu pelayanan berupa frekuensi, rataan, presentase tabulasi silang, rataan skor, serta uji regresi linear berganda untuk menganalisis pengaruh artibut mutu terhadap kepuasan konsumen, dengan sebelumnya dilakukan uji validitas dan reliabilitas. Karakteristik klien diolah dengan tabel kontigensi, dan korelasi rank Spearman. Penilaian tingkat kepentingan dan harapan menggunakan analisis Importance Performance Analysis (IPA). Tingkat kepuasan responden secara menyeluruh untuk melihat tingkat kepentingan dari atribut-atribut produk/jasa menggunakan analisis customer satisfaction index (CSI). Hasil Uji Validitas memperlihatkan bahwa 14 atribut valid pada dimensi-dimensi kenyataan dan 20 atribut lainnya tidak valid. Pada dimensi-dimensi harapan 23 atribut valid dan 11 atribut lainnya tidak valid. Uji Korelasi menunjukkan bahwa ketiga peubah independen berkorelasi dengan peubah dependen dengan koefisien korelasi lebih dari 0,4. Uji Regresi Linear berganda menunjukkan bahwa ketiga peubah independen dapat menerangkan lebih dari $50 \%$ perubahan di peubah dependen. Customer Satisfaction Index adalah 76,84\%. Berdasarkan perhitungan didapatkan hasil CSI 0,768 menunjukkan bahwa tingkat indeks kepuasan pelanggan terletak pada rentang 0,66-0,88 artinya puas terhadap kinerja PT Mediacomm Citra Perdana.
\end{abstract}

Kata kunci: model mutu, pelayanan, kepuasan pelanggan

\section{ABSTRACT}

To achieved customer satisfaction, therefore the performance and quality service must be employed according to the standard. PT Mediacomm Citra Perdana is a company engaged in the communication sector with focusing on advertising. Competition is inevitable for PT. Mediacomm Citra Perdana while looking prospective client and advertise its task. Work culture while also serve as tradition but also play an important role in the terms of speed, accurate and professionalism. The study of Model of Customer Satisfaction in PT Mediacomm Citra Perdana is purposely conducted for: (1) To Identify Customer Perception; (2) To analyze the Effect of Product Quality; (3) To Identify Variables that Influenced Quality Products, Services and Marketing Power (in terms of Management) by PT

\footnotetext{
*) Korespondensi:

Gd. Mina Mitra Bahari Jl. Medan Merdeka Barat, Jakarta; email: roydharmamuliawan@gmail.com
} 
Mediacomm Citra Perdana. The data collected by secondary data of using survey data with Likert scale to describe the characteristics of the consumer, the service and quality of the process (frequency, mean, percentage of cross tabulation, the average scores). Multiple linear regression are also used to analyze the influence of quality attributes on customer satisfaction. The data are also used for test the validity and the reliability. The characteristics of the clients are processed with Contigency Table and Spearman Rank Correlation. The assessment of importance level and customer expectation is analyzed with Importance Performance Analysis. For overall satisfaction of customer with regards to product/service attribute analyzed with Customer Satisfaction Index (CSI). Validity result shows 14 valid attribute on realitydimension while the other 20 is invalid on reality-dimension. On the expectation-dimensions, 23 attribute are recorded its validiy while the other 11 attribute in invalid. Correlation test shows, the three independent variables correlated with the dependent variable with a correlation coefficient $>0,4$. Multiple regression shows, three independent variables explained $>50 \%$ change in the dependent variable. Customer Satisfaction Index are at level $76,84 \%$. Based on the calculation, CSI result on 0,768 indicate the satisfaction level index are positioned in the range $0,66-0,88$ which means PT. Mediacomm Citra Perdana gives excellent performance.

Key words: customer satisfaction, quality model, services

\section{PENDAHULUAN}

Pada saat ini, pelaku bisnis berada dalam lingkungan yang sangat kompetitif, dimana keinginan dan kebutuhan pelanggan harus dipenuhi bagi yang ingin memenangkan persaingan tersebut (meeting the needs of customers). Perhatian penuh terhadap mutu menjadi persyaratan mutlak, karena pada umumnya pelanggan menginginkan produk lebih cepat (faster), lebih murah (cheaper) dan lebih baik (better). Ketiga hal tersebut, berkaitan dengan dimensi waktu yang menggambarkan kecepatan dan kemudahan atau kenyamanan untuk memperoleh produk tersebut, dimensi biaya yang menggambarkan harga atau ongkos dari suatu produk dan dimensi mutu produk. Mutu pada definisi strategik adalah segala sesuatu yang mampu memenuhi keinginan atau kebutuhan pelanggan (Gaspersz, 2005).

Indonesia sebagai negara yang mempunyai populasi penduduk terbesar no. 4 di dunia memiliki jumlah penduduk 241.452.952 jiwa, menjadikan negara ini harus memiliki penerapan ilmu teknologi yang sangat maju sebagai alat untuk mempermudah arus komunikasi dan transportasi. Periklanan adalah suatu proses komunikasi massa yang melibatkan sponsor tertentu, yakni pemasang iklan, yang membayar jasa sebuah media massa untuk penyiaran iklannya. Citra merek merupakan nilai utama pemasaran dan brand telah menjadi unsur krusial yang berkontribusi terhadap kesuksesan sebuah organisasi pemasaran. Keputusan pembelian adalah keputusan yang diambil oleh pembeli sebenarnya dari sejumlah keputusan. Mawara
(2013) mengatakan bahwa periklanan dan citra merek berpengaruh nyata terhadap keputus-an pembelian motor merek yamaha.

PT Mediacomm Citra Perdana merupakan salah satu contoh sebuah biro iklan. PT Mediacomm Citra Perdana adalah sebuah perusahaan yang bergerak di bidang jasa komunikasi dalam bentuk iklan. Dalam pelaksanaannya pembuatan iklan dan pencarian klien, PT Mediacomm Citra Perdana tidak dapat menghindarkan persaingan yang ada. Persaingan diantara biro-biro iklan muncul dalam hal mutu pelayanan dan pelaksanaan penciptaan iklan. Pertumbuhan perusahaan periklanan yang kian kompetitif, telah memotivasi pihak PT Mediacomm Citra Perdana untuk tetap bertahan dalam persaingan tersebut. PT Mediacomm Citra Perdana begitu memperhatikan kepuasan dari kliennya, sehingga pelayanan dan penciptaan iklan menjadi hal yang diutamakan. PT Mediacomm Citra Perdana menggunakan tenaga profesional di bidangnya dalam penciptaan iklan sebagai upaya untuk memuaskan klien, sehingga PT Mediacomm Citra Perdana dapat bertahan dalam dunia periklanan yang penuh dengan persaingan. Hal ini terbukti dengan tetap bertahannya PT Mediacomm Citra Perdana sebagai biro iklan yang perlu dipertimbangkan di kota Jakarta ini. Penelitian tentang kepuasan pelanggan sudah banyak dilakukan, antara lain Rizan \& Anjarestu (2013) menerangkan bahwa kepuasan pelanggan untuk surat kabar dipengaruhi oleh mutu produk dan personal selling, penelitian Sasotyo (2010) menyimpulkan kepuasan pelanggan dipengaruhi oleh mutu produk dan periklanan. Penelitian untuk kepuasan pelanggan lainnya adalah penelitian Tanuwijaya \& Anshori 
(2013) menerangkan bahwa mutu layanan dan produk mempengaruhi kepuasan pelanggan dalam perusahaan Pipop Copy yang bergerak dalam bidang jasa perfotokopian. Penelitian lainnya Putri \& Nurcahya (2014) menerangkan mutu pelayanan dan produk kredit Multiguna berpengaruh positif dan signifikan secara simultan terhadap kepuasan nasabah kredit PT. Pembangunan Daerah Bali Cabang Utama Denpasar. Penelitian selanjutnya oleh Pusparani \& Rastini (2014) menerangkan mutu produk dan brand image berpengaruh pada kepuasan konsumen kamera DSLR Canon, sedangkan Mulyono et al (2007) menerangkan bahwa kualitas produk adalah peubah paling berpengaruh terhadap kepuasan konsumen dibandingkan dengan peubah mutu layanan.

Tujuan kajian adalah (1) Mengidentifikasi persepsi pelanggan terhadap mutu produk, pelayanan jasa dan tenaga pemasaran PT MediaComm Citra Perdana, (2) Menganalisis pengaruh mutu produk, pelayanan jasa dan tenaga pemasaran terhadap kepuasan pelanggan yang berimplikasi pada kinerja PT Mediacomm Citra Perdana, dan (3) Mengidentifikasi faktor mutu produk, pelayanan jasa dan Tenaga pemasaran yang perlu diperbaiki dan dipertahankan oleh PT Mediacomm Citra Perdana.

\section{METODE PENELITIAN}

Lokasi kajian ini dilaksanakan di PT Mediacomm Citra Perdana, komplek perkantoran Tanjung Mas Raya Blok B1-24 Lantai 3 Tanjung Barat Jakarta Selatan dan dilakukan pada bulan Februari-Agutus 2014. Pengolahan dan analisis data dilakukan dua tahap, yaitu tahap pertama Uji validitas, yaitu untuk menguji validitas instrumen berupa kuesioner. Pengujian disini menggunakan rumus korelasi produk moment Pearson (Arikunto, diacu dalam Diana, 2008). $\mathrm{n} \sum \mathrm{xy}-\left(\sum \mathrm{x}\right)\left(\sum \mathrm{y}\right) \mathrm{rxy}=\mathrm{O}\left[\mathrm{n} \sum \mathrm{x} 2-\left(\sum \mathrm{x}\right) 2\right]\left[\mathrm{n} \sum \mathrm{y} 2-\left(\sum \mathrm{y}\right) 2\right]$ Keterangan:

$\mathrm{r} \quad=$ Koefisien korelasi antara peubah $\mathrm{X}$ dan $\mathrm{Y}$

$\mathrm{n} \quad=$ Jumlah contoh

$\mathrm{X}, \mathrm{Y}=$ Skor masing-masing peubah

Bila rhitung > rtabel, maka pengujian instrumen valid. Sebaliknya bila rhitung $<$ rtabel, maka pengujian instrumen tidak valid.

Setelah uji validitas maka dilakukan uji reliabilitas untuk menguji konsistensi suatu instrumen dalam mengukur konsep yang harus diukur atau melakukan fungsi ukurnya. Dalam penelitian ini uji reliabilitas dilakukan dengan menghitung Cronbach's Alpha dari masing-masing instrumen dalam suatu variabel. Instrumen yang dipakai dalam peubah variabel dikatakan andal (reliabel) bila memiliki Cronbach's alpha lebih dari 0,6 (Nunnaly, 1978). Rumus Cronbach's Alpha (Kountur, 2003):

$$
\rho_{\alpha}=\frac{N}{N-1} \frac{\sigma_{A}^{2}-\sum \sigma_{i}^{2}}{\sigma_{A}^{2}}
$$

Dimana:

$$
\begin{array}{ll}
\rho_{\alpha} & =\text { Reliabilitas instrumen } \\
\mathrm{N} & =\text { Banyak butir pertanyaan } \\
\sigma_{A}^{2} & =\text { Ragam total } \\
\sum \sigma_{i}^{2} & =\text { Jumlah ragam butir }
\end{array}
$$

Pada Tahap kedua dilakukan analisis data dengan analisis Regresi Linear berganda yang terdiri dari tiga peubah bebas (independent variable) dan satu peubah terikat (dependent variable): (1) Peubah bebas $(X)$ dalam penelitian ini terdiri dari $X_{1}$ (mutu produk), $X_{2}$ (pelayanan jasa) dan $X_{3}$ (tenaga pemasaran) dan $Y$ (kepuasan pelanggan). Hal tersebut dapat dinyatakan dalam persamaan berikut: $\hat{Y}=b o+b_{1} X_{1}+b_{2} X_{2}+b_{3} X_{3}$

Untuk analisis seluruh peubah bebas, yaitu mutu jasa pelayanan dan kinerja perusahaan secara bersama-sama mempunyai pengaruh terhadap peubah kepuasan pelanggan, dilakukan sebagai berikut:

1. Kriteria pengujian hipotesis

$\mathrm{H}_{\mathrm{o}}: \mathrm{b}_{\mathrm{ij}}=0$, artinya tidak ada pengaruh mutu pelayanan terhadap kepuasan nasabah.

$H_{o}: b_{i j} \neq 0$, artinya ada pengaruh mutu pelayanan atau kinerja terhadap kepuasan nasabah.

2. Penentuan taraf nyata, yaitu $(0,05)$

Analisis selanjutnya dari tahapan ini adalah Importance Performance Analisis (IPA) yang berdasarkan hasil penilaian tingkat kepentingan dan harapan suatu jasa. Untuk menghitung tingkat kesesuaian pelanggan dapat dilakukan dengan melakukan perbandingan rataan skor harapan dan kepentingan, yang dapat menunjukkan tingkat kepuasan pelanggan terhadap kinerja jasa yang dihasilkan. Rumus yang digunakan adalah:

$$
\mathrm{Tki}=\frac{X i}{Y i} \times 100 \%
$$

Dimana:

Tki : tingkat kesesuaian responden

$\mathrm{Xi}$ : rataan skor penilaian pelaksanaan (kinerja) perusahaan 
Yi : rataan skor penilaian kepentingan (harapan pelanggan)

Tahapan akhir analisis tahap kedua menggunakan Customer Satisfaction Index (CSI) yang merupakan fungsi dari weighted avarage (WA) dibagi highest scale (skala maksimum adalah 5), dapat dinyatakan dalam rumus berikut:

$$
C S I=\frac{W A}{H S} \times 100 \%
$$

\section{HASIL DAN PEMBAHASAN}

PT Mediacomm Citra Perdana didirikan dengan latar belakang sebagai divisi pemasaran sebuah perusahaan teknologi informasi di tahun 1998. Berbekal jaringan mitra bisnis yang dimilikinya, maka PT Mediacomm Citra Perdana memulai bisnis baru dalam bidang periklanan (advertising) dan penyelenggaraan acara (event organizer). Budaya kerja yang dijadikan tradisi, khususnya di dalam pelayanan, adalah cepat, akurat dan profesional. PT Mediacomm Citra Perdana telah bekerjasama dengan perusahaan swasta maupun lembaga pemerintah. Setiap komitmen dan tanggungjawab yang dijalaninya telah memberikan PT Mediacomm Citra Perdana berbagai kesempatan dan tantangan untuk membentuk suatu hasil kerja dan kinerja yang baik. PT Mediacomm Citra Perdana dipimpin seorang Direktur yang membawahi seorang manager dan dua belas orang staf.

\section{Uji Validitas}

Validitas adalah ketepatan atau presisi instrumen untuk mengukur apa yang ingin dukur. Dalam pengujian instrumen pengumpulan data, validitas dapat dibagi menjadi validitas faktor dan validitas item. Validitas faktor diukur ketika item yang disusun menggunakan lebih dari satu faktor (antara faktor-faktor lain yang satu dengan tidak ada kesamaan). Pengukuran validitas dilakukan ini dengan mengkorelasikan skor faktor (penjumlahan item dalam satu faktor) dengan total skor faktor, sedangkan validitas item pengukuran dengan cara mengkorelasikan skor item dengan skor total item.

Validitas item ditunjukkan dengan adanya korelasi atau dukungan total item (skor total) dengan perhitungan mengkorelasikan skor item dengan skor total item. Dari hasil perhitungan korelasi diperoleh koefisien korelasi untuk mengukur tingkat validitas item dan untuk menentukan apakah item bernilai atau tidak.
Dalam menentukan apakah valid atau tidak item yang akan digunakan, dilakukan uji signifikansi koefisien korelasi pada taraf nyata 0,05. Item dianggap valid jika berkorelasi nyata terhadap skor total. Cara lain dengan membuat penilaian langsung dari koefisien korelasi, yaitu batasan nilai korelasi minimal 0.30, karena semua item yang mencapai koefisien korelasi minimal 0.30 daya pembeda dianggap memuaskan.

Hasil uji validitas terhadap seluruh dimensi pada penelitian ini dapat dilihat pada Tabel 1 .

Tabel 1. Hasil uji validitas data

\begin{tabular}{lccc}
\hline \multicolumn{1}{c}{ Dimensi } & $\begin{array}{c}\text { Jumlah } \\
\text { perta- } \\
\text { nyaan }\end{array}$ & $\begin{array}{c}\text { Perta- } \\
\text { nyaan } \\
\text { valid }\end{array}$ & $\begin{array}{c}\text { Pertanya- } \\
\text { an tidak } \\
\text { valid }\end{array}$ \\
\hline Kinerja mutu produk & 6 & 5 & 1 \\
Kinerja pelayanan & 12 & 4 & 8 \\
Kinerja pemasaran & 6 & 0 & 6 \\
Kepuasan kinerja & 10 & 5 & 5 \\
Kepentingan mutu & 6 & 3 & 3 \\
produk & 12 & 7 & 5 \\
Kepentingan pelayanan & 6 & 5 & 1 \\
Kepentingan pemasaran & 10 & 8 & 2 \\
Kepuasan kepentingan & & & \\
\hline
\end{tabular}

\section{Uji Reliabilitas}

Reliabilitas adalah indeks yang menunjukkan suatu alat pengukur dapat dipercaya atau diandalkan. Ketika suatu alat ukur yang digunakan untuk mengukur dua kali gejala yang sama dan hasil yang diperoleh pengukuran relatif konsisten maka alat ukur dapat diandalkan atau dengan kata lain, reliabilitas menunjukkan konsistensi suatu alat ukur dalam mengukur gejala yang sama. Tabel 2 memperlihatkan hasil uji reliabilitas dengan SPSS (Statistical Package For Social Science).

Tabel 2. Hasil uji reliabilitas data

\begin{tabular}{lcc}
\hline \multicolumn{1}{c}{ Atribut } & Cronbach's Alpha & N of Items \\
\hline Produk & 0,734 & 6 \\
Pelayanan & 0,663 & 6 \\
Pemasaran & 0,547 & 2 \\
Kepuasan & 0,647 & 9 \\
Produk & 0,616 & 4 \\
Pelayanan & 0,648 & 12 \\
Pemasaran & 0,669 & 5 \\
Kepuasan & 0,676 & 10 \\
\hline
\end{tabular}

\section{Analisis Regresi Linear Berganda}

Persamaan umum regresi linear berganda adalah $\widehat{Y}=a+b_{1} X_{1}+b_{2} X_{2}+b_{3} X_{3} \ldots .+z_{n} X_{n}$. Pada 
kajian ini, $\mathrm{Y}$ sebagai peubah terikat, $\mathrm{X}_{1} \mathrm{X}_{2}$ dan $\mathrm{X}_{3}$ Sebagai peubah bebas, a adalah konstanta (intersept) dan $b$ adalah koefisien regresi pada masing-masing peubah bebas.

a. Uji F hitung :

Dilihat dari hasil di atas $\mathrm{F}$ hitung $(32,696)>\mathrm{F}$ Tabel $(3,97)$, dapat dikatakan model sudah tepat dan juga nilai peluang $<$ taraf nyata $(0,000<$ 0,005), maka model $\widehat{Y}=a+b_{1} X_{1}+b_{2} X_{2}+b_{3}$ $\mathrm{X}_{3} \ldots .+\mathrm{Zn}_{\mathrm{n}} \mathrm{X}_{\mathrm{n}}$ yang digunakan dapat diterima.

b. Uji t

Setelah menguji signifikansi persamaan regresi, selanjutnya diuji apakah masing-masing peubah bebas $\left(\mathrm{X}_{1}=\right.$ mutu produk, $\mathrm{X}_{2}=$ pelayanan, $X_{3}=$ pemasaran) mempunyai pengaruh nyata terhadap peubah terikat $(\mathrm{Y}=$ kepuasan pelanggan), untuk itu dilakukan uji t.

$\begin{array}{ll}\mathrm{t} \text { tabel } & =1,984 \\ \mathrm{t} \text { hitung }\left(\mathrm{X}_{1}\right) & =2,094 \\ \mathrm{t} \text { hitung }\left(\mathrm{X}_{2}\right) & =5,465 \\ \mathrm{t} \text { hitung }\left(\mathrm{X}_{3}\right) & =3,015\end{array}$

Setelah diketahui nilai $t$, selanjutnya dianalisis masing-masing peubah bebas terhadap peubah terikat.

1. Mutu produk $\left(\mathrm{X}_{1}\right)$

t hitung $(2,094)>t$ tabel $(1,984)$, maka Ho ditolak, artinya mutu produk berpengaruh nyata dengan kepuasan pelanggan.

2. Pelayanan $\left(X_{2}\right)$

t hitung $(5,465)>t$ tabel $(1,984)$, maka Ho ditolak, artinya pelayanan berpengaruh secara nyata terhadap kepuasan pelanggan.

3. Pemasaran $\left(X_{3}\right)$

$\mathrm{t}$ hitung $(3,015)>\mathrm{t}$ tabel $(1,984)$, maka Ho ditolak, artinya pemasaran berpengaruh secara nyata terhadap kepuasan pelanggan.

Persamaan Regresi

Tabel 3. Koefisien persamaan regresi

\begin{tabular}{llc}
\hline \multirow{2}{*}{ Model } & Unstandardized coefficients \\
& & B \\
\hline 1 & (Constant) & 3,65 \\
& Mutu produk &, 050 \\
& Pelayanan &, 020 \\
& Pemasaran &, 110 \\
\hline
\end{tabular}

Dari Tabel 3, didapatkan persamaan regresi linear berganda adalah:

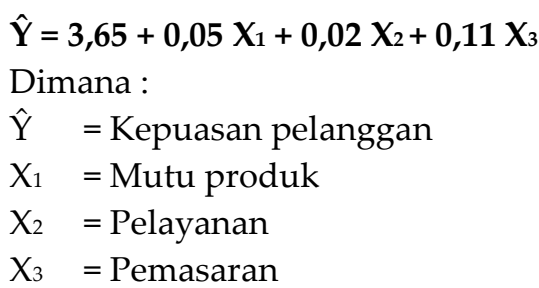

Dari persamaan regresi tersebut dapat diuraikan sebagai berikut:

1. Konstanta $(a)=3,65$, artinya jika mutu produk $\left(X_{1}\right)$, pelayanan $\left(X_{2}\right)$ dan pemasaran $\left(X_{3}\right)$ nilainya nol, maka hasil kepuasan konsumen (Y) adalah 3,65.

2. Koefisien regresi 0,05 , berarti jika mutu produk ( $\left.\mathrm{X}_{1}\right)$ mengalami kenaikan 1 unit, maka hasil output (Y) mengalami peningkatan 0,05 unit.

3. Koefisien regresi 0,02, berarti jika pelayanan $\left(\mathrm{X}_{2}\right)$ mengalami kenaikan 1 unit, maka hasil output (Y) mengalami peningkatan 0,02 unit.

4. Koefisien regresi 0,11, berarti jika intensitas pemasaran $\left(\mathrm{X}_{3}\right)$ mengalami kenaikan 1 unit, maka hasil output (Y) mengalami peningkatan 0,11 unit.

\section{Analisis IPA}

Dari perhitungan skor Likert, dengan nilai rataan tingkat kinerja pelayanan 3,83 dari skala 15, yaitu mutu pelayanan mencakup kehandalan (reliability), keresponsifan (responsiveness), keyakinan (assurance), empati (emphaty) dan wujud (tangible) pada PT Mediacomm Citra Perdana cukup baik. Tingkat kepentingan pelayanan nasabah adalah 3,89 (penting bagi nasabah), seperti terlihat pada Tabel 4. Secara garis besar terlihat bahwa kinerja pelayanan petugas PT Mediacomm Citra Perdana yang diberikan telah sesuai dengan apa yang diharapkan nasabah.

\section{Analisis CSI}

Nilai rataan tingkat kepentingan dan tingkat kepuasan masing-masing atribut digunakan untuk menghitung CSI. Berdasarkan perhitungan yang terdapat pada Tabel 5 didapatkan hasil CSI 0,768. Hal ini menunjukkan bahwa tingkat indeks kepuasan pelanggan terletak pada 0,66-0,80, berarti pelanggan merasa puas terhadap kinerja pelayanan PT Mediacomm Citra Perdana. 
Tabel 4. Tingkat penilaian kinerja dan kepentingan

\begin{tabular}{|c|c|c|c|c|c|c|}
\hline $\begin{array}{c}\text { Daftar } \\
\text { Pertanyaan }\end{array}$ & $\begin{array}{c}\text { Penilaian } \\
\text { Kinerja }\end{array}$ & $\begin{array}{c}\text { Penilaian } \\
\text { Kepentingan }\end{array}$ & $X$ & $\mathrm{Y}$ & $\begin{array}{c}\text { Tingkat } \\
\text { Kesesuaian }\end{array}$ & Rangking \\
\hline 1. & 356 & 374 & 3,56 & 3,74 & 95,19 & 16 \\
\hline 2. & 337 & 307 & 3,37 & 3,07 & 109,8 & 1 \\
\hline 3. & 333 & 380 & 3,33 & 3,80 & 87,63 & 19 \\
\hline 4. & 366 & 403 & 3,66 & 4,03 & 90,82 & 18 \\
\hline 5. & 381 & 370 & 3,81 & 3,70 & 103 & 3 \\
\hline 6. & 321 & 380 & 3,21 & 3,80 & 84,47 & 21 \\
\hline 7. & 385 & 401 & 3,85 & 4,01 & 96,01 & 15 \\
\hline 8. & 370 & 385 & 3,70 & 3,85 & 96,1 & 14 \\
\hline 9. & 380 & 400 & 3,80 & 4,00 & 95 & 17 \\
\hline 10. & 403 & 403 & 4,03 & 4,03 & 100 & 12 \\
\hline 11. & 367 & 429 & 3,67 & 4,29 & 85,55 & 20 \\
\hline 12. & 400 & 399 & 4,00 & 3,99 & 100,3 & 10 \\
\hline 13. & 383 & 396 & 3,83 & 3,96 & 96,72 & 13 \\
\hline 14. & 366 & 365 & 3,66 & 3,65 & 100,3 & 10 \\
\hline 15. & 380 & 379 & 3,80 & 3,79 & 100,3 & 10 \\
\hline 16. & 403 & 402 & 4,03 & 4,02 & 100,2 & 11 \\
\hline 17. & 370 & 366 & 3,70 & 3,66 & 101,1 & 7 \\
\hline 18. & 380 & 380 & 3,80 & 3,80 & 100 & 12 \\
\hline 19. & 402 & 400 & 4,02 & 4,00 & 100,5 & 9 \\
\hline 20. & 386 & 380 & 3,86 & 3,80 & 101,6 & 6 \\
\hline 21. & 401 & 401 & 4,01 & 4,01 & 100 & 12 \\
\hline 22. & 393 & 393 & 3,93 & 3,93 & 100 & 12 \\
\hline 23. & 426 & 422 & 4,26 & 4,22 & 100,9 & 8 \\
\hline 24. & 400 & 386 & 4,00 & 3,86 & 103,6 & 2 \\
\hline 25. & 401 & 401 & 4,01 & 4,01 & 100 & 12 \\
\hline 26. & 379 & 379 & 3,79 & 3,79 & 100 & 12 \\
\hline 27. & 400 & 400 & 4,00 & 4,00 & 100 & 12 \\
\hline 28. & 393 & 393 & 3,93 & 3,93 & 100 & 12 \\
\hline 29. & 429 & 419 & 4,29 & 4,19 & 102,4 & 4 \\
\hline 30. & 399 & 397 & 3,99 & 3,97 & 100,5 & 9 \\
\hline 31. & 397 & 397 & 3,97 & 3,97 & 100 & 12 \\
\hline 32. & 370 & 368 & 3,70 & 3,68 & 100,5 & 9 \\
\hline 33. & 379 & 371 & 3,79 & 3,71 & 102,2 & 5 \\
\hline 34. & 401 & 400 & 4,01 & 4,00 & 100,3 & 10 \\
\hline Rataan & & & 3,83 & 3,89 & & \\
\hline
\end{tabular}

\section{KESIMPULAN}

1. Penilaian pelanggan yang memuaskan terhadap PT Mediacom Citra Perdana dijabarkan atas Mutu Produk PT Mediacomm Citra Perdana, secara umum konsumen menyatakan puas dengan produk yang diberikan. Hal ini ditandakan dengan nilai rataan 3,48, Pelayanan Jasa, secara umum konsumen menyatakan puas dengan pelayanan jasa yang diberikan, hal ini ditandakan dengan nilai rataan 3,75, Tenaga Pemasaran, secara umum konsumen menyatakan puas dengan tenaga pemasaran, hal ini ditandakan dengan nilai rataan 3,8, Tidak ada gap antara mutu produk, pelayanan jasa dan tenaga pemasaran yang diberikan kepada konsumen (kenyataan) dengan harapan konsumen, hal ini ditandakan dengan rataan kenyataan $>$ rataan harapan.

2. Mutu produk, pelayanan jasa dan tenaga pemasaran memiliki pengaruh sangat penting terhadap kepuasan pelanggan, sehingga kinerja PT Mediacomm Citra Perdana dikatakan baik, yang ditandai dengan adanya kepuasan pelanggan

3. Faktor-faktor yang perlu dipertahankan oleh PT Mediacomm Citra Perdana meliputi Mutu Produk (Konsep ide PT Mediacomm Citra Perdana harus sangat menarik, kreatif, unik, dan klasik) agar dapat meningkatkan branding perusahaan dan meningkatkan penjualan perusahaan klien; Pelayanan Jasa (cepat, tepat, dapat memberikan pelayanan seketika, peka terhadap kebutuhan pelanggan, dan menang- 
gapi keluhan pelanggan sangat baik), diharapkan memiliki kemampuan riset yang baik, ahli dalam perencanaan media, dan memberikan layanan menyeluruh; Tenaga Pemasaran (produk knowledge yang baik, tenaga pemasaran lokal dan ekspat yang berpengalaman serta turnover tenaga pemasaran yang rendah).

4. Faktor-faktor yang perlu diperbaiki oleh PT Mediacomm Citra Perdana meliputi Mutu
Produk (konsep ide mengikuti perkembangan jaman, aplikatif dan mudah dimengerti), Pelayanan Jasa (klien mengharapkan agency service fee bisa lebih bersaing, pekerjaan dapat selesai tepat waktu meningkatkan sikap keramahan terhadap klien), Tenaga Pemasaran (memberikan informasi yang benar dan jelas).

Tabel 5. Perhitungan CSI

\begin{tabular}{|c|c|c|c|c|c|}
\hline $\begin{array}{l}\text { Nomor } \\
\text { Atribut }\end{array}$ & $\begin{array}{c}\text { Skor rataan } \\
\text { Tingkat } \\
\text { Kepentingan }\end{array}$ & $\begin{array}{c}\text { Importance } \\
\text { Weighting Factor }\end{array}$ & $\begin{array}{c}\text { Importance } \\
\text { Weighting Factor (\%) }\end{array}$ & $\begin{array}{c}\text { Skor rataan } \\
\text { Tingkat Kinerja }\end{array}$ & Weighted Score \\
\hline & (a) & (b) & (c) & (d) & (e) \\
\hline 1. & 3,74 & 0,028 & 2,828 & 3,56 & 0,101 \\
\hline 2. & 3,07 & 0,023 & 2,321 & 3,37 & 0,078 \\
\hline 3. & 3,80 & 0,029 & 2,873 & 3,33 & 0,096 \\
\hline 4. & 4,03 & 0,030 & 3,047 & 3,66 & 0,112 \\
\hline 5. & 3,70 & 0,028 & 2,798 & 3,81 & 0,107 \\
\hline 6. & 3,80 & 0,029 & 2,873 & 3,21 & 0,092 \\
\hline 7. & 4,01 & 0,030 & 3,032 & 3,85 & 0,117 \\
\hline 8. & 3,85 & 0.029 & 2,911 & 3,70 & 0,108 \\
\hline 9. & 4,00 & 0,030 & 3,024 & 3,80 & 0,115 \\
\hline 10. & 4,03 & 0,030 & 3,047 & 4,03 & 0,123 \\
\hline 11. & 4,29 & 0,032 & 3,244 & 3,67 & 0,119 \\
\hline 12. & 3,99 & 0,030 & 3,017 & 4,00 & 0,121 \\
\hline 13. & 3,96 & 0,030 & 2,994 & 3,83 & 0,115 \\
\hline 14. & 3,65 & 0,028 & 2,760 & 3,66 & 0,101 \\
\hline 15. & 3,79 & 0,029 & 2,866 & 3,80 & 0,109 \\
\hline 16. & 4,02 & 0,030 & 3,039 & 4,03 & 0,122 \\
\hline 17. & 3,66 & 0,028 & 2,767 & 3,70 & 0,102 \\
\hline 18. & 3,80 & 0,029 & 2,873 & 3,80 & 0,109 \\
\hline 19. & 4,00 & 0,030 & 3,024 & 4,02 & 0,122 \\
\hline 20. & 3,80 & 0,029 & 2,873 & 3,86 & 0,111 \\
\hline 21. & 4,01 & 0,030 & 3,032 & 4,01 & 0,122 \\
\hline 22. & 3,93 & 0,030 & 2,971 & 3,93 & 0,117 \\
\hline 23. & 4,22 & 0,032 & 3,191 & 4,26 & 0,136 \\
\hline 24. & 3,86 & 0,029 & 2,918 & 4,00 & 0,117 \\
\hline 25. & 4,01 & 0,030 & 3,032 & 4,01 & 0,122 \\
\hline 26. & 3,79 & 0,029 & 2,866 & 3,79 & 0,109 \\
\hline 27. & 4,00 & 0,030 & 3,024 & 4,00 & 0,121 \\
\hline 28. & 3,93 & 0,030 & 2,971 & 3,93 & 0,117 \\
\hline 29. & 4,19 & 0,032 & 3,168 & 4,29 & 0,136 \\
\hline 30. & 3,97 & 0,030 & 3,002 & 3,99 & 0,120 \\
\hline 31. & 3,97 & 0,030 & 3,002 & 3,97 & 0,119 \\
\hline 32. & 3,68 & 0,028 & 2,782 & 3,70 & 0,103 \\
\hline 33. & 3,71 & 0,028 & 2,805 & 3,79 & 0,106 \\
\hline 34. & 4,00 & 0,030 & 3,024 & 4,01 & 0,121 \\
\hline \multicolumn{6}{|l|}{ Total } \\
\hline Weighted & & & & & 3,842 \\
\hline Total & 132,26 & & 100 & & 0,768 \\
\hline $\begin{array}{l}\text { Satisfaction } \\
\text { Index }\end{array}$ & & & & & $(76,84)$ \\
\hline
\end{tabular}




\section{DAFTAR PUSTAKA}

Andrianto, Noky H \& Idris. (2013). Pengaruh Kualitas Produk, Citra Merek, Harga Dan Promosi Terhadap Keputusan Pembelian Mobil Jenis Mpv Merek Toyota Kijang Innova Di Semarang. DIponegoro Journal of Management; Volume 2(3): 1-10. http://eprints.undip.ac.id/39642 [16 Februari 2015]

Diana, N. 2008. Analisis Pengaruh Mutu Pelayanan Bank Mandiri Cabang Yogyakarta Terhadap Kepuasan Nasabah. http://www.skripsi-tesis.com ( 21 Februari 2009).

Gaspersz, V. 2005. Total Quality Management. Gramedia Pustaka Utama, Jakarta dan Armstrong, 1997. Dasar-Dasar Pemasaran (Terjemahan, Jilid 1). Intermedia, Jakarta.

Kountour, R. 2003. Metode Penelitian untuk Penulisan Skripsi dan Tesis. Edisi Pertama. Jakarta : Penerbit PPM.

Mawara, ZR. (2013). Periklanan Dan Citra Merek Pengaruhnya Terhadap Keputusan Pembelian Kendaraan Bermotor Yamaha. Jurnal Emba 833, 1(3): 826-835. Juni 2013, http://ejournal.unsrat.ac.id/index.php/emba /article/view/1891 [16 Februari 2014].

Mulyono BH, Yoestini, Nugraheni R \& Kamal M. (2007). Analisis Pengaruh Kualitas Produk Dan Kualitas Layanan Terhadap Kepuasan Konsumen (Studi Kasus Pada Perumahan Puri Mediterania Semarang). Jurnal Studi Manajemen \& Organisasi; Vol 4 (2) : 91-100. http://ejournal.undip.ac.id/index.php/smo/a rticle/view/4253 [9 Februari 2014].

Pusparani, PAY \& Ni Made Rastini. (2014). Pengaruh Kualitas Produk Dan Brand Image Terhadap Kepuasan Konsumen Dan Loyalitas Pelanggan Kamera Canon Digital
Single Lens Reflex (DLSR) Di Kota Denpasar. E-Jurnal Manajemen Universitas Udayana; 3(5): 1311-1319. http://ojs.unud.ac. id/index.php/Manajemen/article/view/7629 [9 Februari 2014].

Putri, AAA \& IK. Nurcahya. 2014. Pengaruh Kualitas Pelayanan Dan Produk Kredit Multiguna Terhadap Kepuasan Nasabah Kredit Pada PT. Bank Pembangunan Daerah Bali Cabang Utama Denpasar. EJurnal Manajemen Universitas Udayana; Vol. 3(2) : 456-474.

http://ojs.unud.ac.id/index.php/Manajemen /article/view/6881 [9 Februari 2014]

Rangkuti, F. 2000. Analisis SWOT Teknik Membedah Kasus Bisnis: Reorientasi, Konsep, dan Strategi untuk Menghadapi Abad 21. Penerbit PT. Gramedia Pustaka Utama, Jakarta.

Rizan, M \& Y Anjarestu. 2013. Pengaruh kualitas produk dan personal selling Terhadap kepuasan pelanggan pada majalah Info bekasi (studi kasus PT. SIBK). Jurnal Riset Manajemen Sains Indonesia (JRMSI) Vol 4(1) : 74-96. [6 Februari 2015].

Sasotyo, YU. 2010. Pengaruh Kualitas Produk dan Periklanan Terhadap Kepuasan Pelanggan Harian Surat Kabar Suara Merdeka (Studi Kasus di Kecamatan Ngaliyan Semarang) Undergraduate thesis, Diponegoro University. eprints.undip.ac.id/24766/1/Yucha.pdf [6 Februari 2015].

Sugiyono. 1999. Statistika Untuk Penelitian. Bandung: CY Alfabeta.

Tanuwijaya, M \& MY. Anshori. 2013. Pengaruh Kualitas Layanan dan Kualitas Produk terhadap Kepuasan Pelanggan Pipop Copy. Jurnal NeO-Bis Vol 7(1): 1-16. [9 Februari 2015]. 